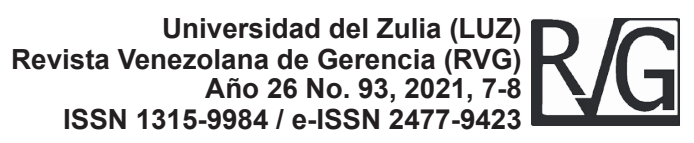

\title{
Editorial Revista Venezolana de Gerencia
}

La actual situación de pandemia en "aproximadamente" un año ha frenado hasta casi la total paralización el correr rutinario de las actividades económicas y sociales. Esto ha afectado sensiblemente la producción de bienes y servicios, con el innegable deterioro económico que esto conlleva. En este sentido, el banco mundial reportaba que a mediados del 2020 enfrentábamos un escenario de recesión aún más crítico que el generado por la segunda guerra mundial.

Si bien, a la fecha, el resultado económico de esta pandemia es aun difícilmente calculable, no así las necesidades de adecuación de las actividades de producción de bienes y servicios a situaciones de confinamiento, total o parcial que permanecerá mientras avance la enfermedad y que, a la luz de las dificultades en: generación, compra y distribución de vacunas, medios para tratamiento y capacidad de negociación internacional, continuará afectando sobre todo a países con débiles sistemas de gestión administrativa. En este sentido el desarrollar y/o implementar mejoras en los sistemas de gestión, sobre todo soportados en los avances tecnológicos que se han logrado en las últimas décadas, se ha convertido en una prioridad y el medio para que la economía encuentre algún ritmo de actividades de subsistencia.

La revolución digital a la cual la industria viene siendo empujada, conocida como industria 4.0, hace uso de tecnologías como análisis de grandes volúmenes de datos "big data", inteligencia artificial, análisis de imágenes para el desarrollo de sus actividades. Estas tecnologías se expresan en el desarrollo de equipos y aplicaciones cada vez más inteligentes y personalizados a los diferentes usuarios, optimizando de esta manera el uso de recursos y su masificación. Sin embargo, el escenario actual ha puesto a prueba las capacidades de estas herramientas para expandirse a casi la totalidad de actividades económicas y sociales como la educación, atención médica, control ciudadano, entre muchas otras.

Por tanto, la labor de la Revista Venezolana de Gerencia (RVG), publicación académica venezolana de la Universidad del Zulia en esta edición $N^{\circ}$ 93 (Enero - marzo 2021) tiene como objetivo central recoger parte de las investigaciones enfocadas en las revoluciones tecnológicas en escenarios presentes y futuros. Asimismo; como complemento, en la Sección TRIMESTRE, se incluyen artículos de gran interés insertos en diversas áreas del conocimiento. 
Editorial

Wilson Manuel Castro Silupu

Se agradece a los autores que nos acompañaron en esta entrega, así como al equipo de árbitros que constantemente velan por que la calidad esté presente de cada uno de los artículos publicados.

\section{Dr. Wilson Manuel Castro Silupu Facultad de Ingeniería de Industrias Alimentarias Universidad Nacional de Frontera}

